\title{
PRODUCTION AND CHARACTERIZATION OF AN ENZYME COMPLEX FROM A NEW STRAIN OF CLOSTRIDIUM THERMOCELLUM WITH EMPHASIS ON ITS XYLANASE ACTIVITY
}

\author{
Werner Bessa Vieira; Leonora Rios de Souza Moreira; Amadeu Monteiro Neto; \\ Edivaldo Ximenes Ferreira Filho*
}

Laboratório de Enzimologia, Departamento de Biologia Celular, Universidade de Brasília, Brasília, DF, Brasil

Submitted: August 07, 2006; Returned to authors for corrections: October 19, 2006 Approved: February 23, 2007.

\begin{abstract}
A new bacterial strain (ISO II) was isolated from manure cow and identified as phylogenetically close to the thermophilic cellulolytic bacterium Clostridium thermocellum. The new strain produced extracellular xylanase, pectinase, mannanase and cellulase activities when grown in liquid culture medium containing banana stem as carbon source. The enzyme production profile after growth on banana stem showed that xylanase and cellulase activities were detected in different incubation periods. An enzyme complex containing xylanase, cellulase and mannanase activities was isolated from culture supernatant samples of strain ISO II. The complex was partially purified by ultrafiltration and gel filtration chromatography on Sephacryl S-300. Zymogram analysis after SDS-PAGE presented at least 05 subunits with xylanase activity. The enzyme showed single protein and xylanase activity bands after electrophoresis under non-denaturing conditions. The hydrolysis of xylan was optimal at temperature range of $55-75^{\circ} \mathrm{C}$ and $\mathrm{pH} 6.0$. Xylanase activity was quite stable at $65^{\circ} \mathrm{C}$, retaining $80 \%$ of its original activity after $12 \mathrm{~h}$ incubation. The apparent $\mathrm{Km}$ values, using insoluble and soluble arabinoxylans as substrates, were 1.54 and $11.53 \mathrm{mg} / \mathrm{mL}$, respectively. Xylanase was activated by dithiothreitol, L-tryptophan and L-cysteine and strongly inhibited by N-bromosuccinimide and $\mathrm{CoCl}_{2}$. The characterization of mannanase showed $\mathrm{Km}$ and temperature optimum of $0.846 \mathrm{mg} / \mathrm{mL}$ and $65^{\circ} \mathrm{C}$, respectively and $\mathrm{pH}$ 8.0. By contrast to xylanase, it was less stable at $65^{\circ} \mathrm{C}$ with half-life of $2.5 \mathrm{~h}$ and inhibited by dithiothreitol and $\mathrm{Ca}^{2+}$.
\end{abstract}

Key words: Clostridium thermocellum; banana stem; xylanase.

\section{INTRODUCTION}

The banana plant produces a residual component named stem. The stem in natura presents $93 \%$ of humidity and parenchymatic cells in abundance (20). In terms of chemical composition, total extractives, holocellulose and lignin account for as much as $47 \%, 45.6 \%$ and $7.4 \%$ of its dry weight, respectively (20). For this reason, stem can be considered an alternative carbon source for enzyme production. The banana stem, grain stalk that supports the banana fruits readily available in tropical and subtropical countries, is normally discarded after the fruit harvesting, either in the "packing houses" or in the delivering centers, contributing to serious environmental problems $(12,17)$. Due to its heterogeneity and complex chemical nature, the lignocellulose biodegradation of banana stem requires the coordinated action of several enzymes, including cellulase, xylanase and mannanase with different specificities to effect extensive hydrolysis to its monomeric components.

Some microorganisms are reported to produce enzyme systems containing multiactivity $(1,3,18)$. For example, $C$. thermocellum and $C$. cellulolyticum, gram-positive, thermophilic and anaerobic bacteria, produce a multienzyme complex (cellulosome) when grown on cellulose as the substrate. In this paper, we describe the isolation, partial purification and

*Corresponding Author. Mailing address: Laboratório de Enzimologia, Departamento de Biologia Celular, Universidade de Brasília, 70910-900, Brasília, DF, Brasil. Tel.: (61) 3307-2152 ou (61) 3273-4608. E-mail: eximenes@unb.br 
characterization of an enzyme complex, containing xylanase, cellulase and mannanase activities from the culture supernatant of a new strain of $C$. thermocellum ISO II grown on banana stem.

\section{MATERIALS AND METHODS}

\section{Chemicals}

Oat spelt xylan, locust bean gum (galactomannan), carboxymethyl cellulose (CMC), p-nitrophenyl- $\beta$-Dglucopyranoside (PNPG), p-nitrophenyl- $\beta$-D-xylopyranoside (PNPX), p-nitrophenyl- $\alpha$-D-arabinofuranoside (PNPA), pnitrophenyl- $\beta$-D-mannopyranoside (PNPM), pectin from citrus fruits, dithiothreitol (DTT), N-bromosuccinimide (NBS), 1-ethyl3-(3-dimethylamino-propyl) carbodiimide (EDC) and diethyl pyrocarbonate (DEPC) were purchased from Sigma Chemical Co. (St. Louis, MO, USA). Banana stem was kindly provided by Francides Gomes da Silva Jr (University of São Paulo, Brazil). Sephacryl S-300 was purchased from Amersham Pharmacia Biotech (Piscataway, NJ, USA). Each experiment below was repeated at least three times. The standard deviation for enzyme assays was less than $\pm 20 \%$ of the mean.

\section{Microorganism and enzyme production}

Clostridium thermocellum strain ISO II was isolated from the manure of cow and identified at the Fundação André Tosello (Campinas, Brazil). Fragments of $16 \mathrm{~S}$ rDNA were PCR amplified and submitted to sequence in an automated sequencer (ALFexpress, Amersham Pharmacia). C. thermocellum strain JW20 was kindly provided by Dr. Lars G. Ljungdahl (University of Georgia, USA). For mannanase, cellulase and xylanase production, 2,0 $\mathrm{mL}$ of spore suspensions of $C$. thermocellum strains ISO II and JW20, obtained from a 7-day-culture, were cultured at $60^{\circ} \mathrm{C}$ for 7 days (early stationary phase) in a prereduced liquid-state medium (9) under anaerobic conditions containing $2 \%(\mathrm{w} / \mathrm{v})$ of powdered banana stem. After the growth procedure, the resulting culture supernatant was centrifuged for $20 \mathrm{~min}$ at $10,400 \mathrm{x}$ and stored at $4^{\circ} \mathrm{C}$ prior enzymatic assays. For enzyme induction, aliquots were harvested every $24 \mathrm{~h}$ during 08 days, and used to estimate the enzyme activity.

\section{Assays}

The hydrolysis of polysaccharides (oat spelt xylan, pectin, galactomannan and CMC) was determined by mixing $50 \mu \mathrm{L}$ de enzyme solution with $100 \mathrm{~mL}$ of substrate $(1 \%$, w/v) in $50 \mathrm{mM}$ sodium acetate buffer, $\mathrm{pH} 5.0$ at $50^{\circ} \mathrm{C}$ for $30 \mathrm{~min}$. The reducing sugars released was measured using the DNS (dinitrosalicylic) method $(4,12)$. Enzyme activities were expressed as $\mu$ mol product formed $\mathrm{min}^{-1} \mathrm{ml}^{-1}$ of enzyme solution, i.e., as IU $\mathrm{mL}^{-1}$. The enzyme activities against PNPX, PNPA, PNPG, PNPM and filter paper were carried out as described elsewhere $(6,21)$. Protein concentration was measured by the method of Bradford (2), using bovine serum albumin as standard. For the kinetic experiments, substrates were used in concentration ranges of $0.5-6,0 \mathrm{mg} \mathrm{mL}^{-1}$ (insoluble oat spelt xylan), $0.5-15 \mathrm{mg} \mathrm{mL}^{-1}$ (soluble oat spelt xylan) and $0.5-6.66 \mathrm{mg} \mathrm{mL}^{-1}$ (galactomannan). $\mathrm{Km}$ and Vmax Values were estimated from Michaelis-Menten equation with a non-linear regression data analysis program (19). The determination of optimum temperature was carried out in the temperature range of 30 to $90^{\circ} \mathrm{C}$. The optimum $\mathrm{pH}$ was determined by measuring the activity at $50^{\circ} \mathrm{C}$ at various $\mathrm{pH}$ values between 3.0 and 9.0. All buffers were adjusted to the same ionic strength with $\mathrm{NaCl}$. The enzyme stability was carried out by pre-incubating the enzyme solution at 55,65 and $70^{\circ} \mathrm{C}$ and removing aliquots at intervals to measure its activity as described above. The activity of the enzyme was also performed in the presence of amino acid modifying (NBS, iodoacetamide, EDC, DEPC and DTT), metals $\left(\mathrm{CuSO}_{4}, \mathrm{ZnSO}_{4}, \mathrm{CaCl}_{2}, \mathrm{FeCl}_{3}, \mathrm{AlCl}_{3}\right.$ and $\mathrm{CoCl}_{2}$ ) and aminoacids (L-tryptophan and L-cysteine). The reaction mixtures contained individual reagents at a final concentration of $10 \mathrm{mM}$ (L-tryptophan, NBS, DTT, iodoacetamide, EDC, DEPC and L-cysteine) and $5.6 \mathrm{mM}\left(\mathrm{CuSO}_{4}\right.$, $\mathrm{ZnSO}_{4}, \mathrm{CaCl}_{2}, \mathrm{FeCl}_{3}, \mathrm{AlCl}_{3}$ and $\mathrm{CoCl}_{2}$ ). Appropriate controls were included in all cases.

\section{Enzyme purification}

All the purification steps were carried out at $10^{\circ} \mathrm{C}$ unless otherwise specified. The culture supernatant was concentrated by ultrafiltration using an Amicon system (Amicon Inc., Beverly, MA 01915, USA) with a $300 \mathrm{kDa}$ cut-off point membrane (PM 300). Aliquots (4 ml) of the concentrate were fractionated by gel filtration on Sephacryl S-300 $(2.4$ x $67 \mathrm{~cm})$ column pre-equilibrated with $50 \mathrm{mM}$ sodium phosphate buffer, $\mathrm{pH}$ 7.0. Fractions of $5.0 \mathrm{ml}$ were collected at a flow rate of 30 $\mathrm{ml} / \mathrm{h}$. Fractions (41-49) with $\beta$-mannanase, $\beta$-xylanase and cellulase activities were pooled, concentrated by freeze-drying and stored for later use at $4^{\circ} \mathrm{C}$. The void volume of Sephacryl S-300 column was determined by using thyroglobulin (669 $\mathrm{kDa}$ ) as molecular weight marker under the same conditions as described above.

\section{Electrophoresis}

Enzyme preparations were submitted to denaturing (SDSPAGE) and non-denaturing electrophoresis on $7.5 \%$ gels by the method of Laemmli (10). After electrophoresis, the gels were stained for protein with silver nitrate (4). Molecular mass standards from Sigma (USA) were used as markers. Replicate denaturing and non-denaturing electrophoretic gels, containing $1 \%$ oat spelt xylan, were submitted to zymogram analysis (16). They were stained for xylanase activity in a Congo red solution $(0.1 \%)$ for $30 \mathrm{~min}$ at room temperature and washed with $1 \mathrm{M} \mathrm{NaCl}$ to remove excess dye and fixed with $0.5 \%$ acetic acid. 


\section{RESULTS AND DISCUSSION}

The partial 16S rDNA sequence of ISO II was compared with the 16S rDNA sequences of organisms available in Ribosomal Database Project (www.cme.msu.edu/RDP/html/index.html) and Genbank (www.ncbi.nlm.nih.gov). Phylogenetic analysis of the partial 16S rDNA sequence of the present strain showed that the highest similarity (93\%) was obtained with the $16 \mathrm{~S}$ rDNA of C. thermocellum. Zhilina et al. (22) described a new strain of Clostridium (Z-7026) showing 94.8, 94.9 and $95.5 \%$ of similarity with $16 \mathrm{~S}$ rDNA sequences of Acetivibrio cellulolyticus, $C$. aldrichii and $C$. thermocellum, respectively.

C. thermocellum strain ISO II was grown on banana stem for determination of the effect of this substrate on xylanase and cellulase production by the bacterium. The enzymes production of $C$. thermocellum strain ISO II was also compared with $C$. thermocellum strain JW20. For convenience, culture conditions (the amount of substrate, temperature, $\mathrm{pH}$, inoculum and incubation period) and enzyme assays were the same for both strains. At different time intervals, the samples were taken and assayed for enzyme activity.

Both strains were able to grow on banana stem. The growth profile of strain ISO II on banana stem was accompanied by a highest peak of xylanase activity $(2.94 \mathrm{IU} / \mathrm{mL})$ at cultivation interval of 140-170 h, while the production of xylanase activity by strain JW20 reached its maximum $(5.14 \mathrm{IU} / \mathrm{mL})$ at $168 \mathrm{~h}$ cultivation. For both strains, CMCase activity was expressed at $20 \mathrm{~h}$ of cultivation in banana stem containing medium. For the growth of strain JW20, an activity peak of $2.4 \mathrm{IU} / \mathrm{mL}$ was observed. CMCase activity remained constant after $72 \mathrm{~h}$ cultivation and was detectable in strain ISO II in much lower level. The highest activity was obtained after $48 \mathrm{~h}$ cultivation with a rapid decrease after this period.

An enzyme complex containing xylanase, cellulase and mannanase activities was isolated from $C$. thermocellum strain ISO II when grown in banana stem and purified by a combination of ultrafiltration and gel filtration procedures. Accordingly, the summary of the purification procedure refers to the purification of xylanase activity. The culture supernatant was concentrated by ultrafiltration with a $300 \mathrm{kDa}$ cut-off point membrane (PM 300). The ultrafiltrate and concentrate were assayed for activity as a matter of course. Mannanase, cellulase and xylanase activities were found in the concentrate, while pectinase and a small molecular mass xylanase activities permeated the ultrafiltration membrane. For further purification, the concentrate was subjected to gel filtration chromatography on Sephacryl S300 (Fig. 1). One peak of protein co-eluted with xylanase, cellulase and mannanase activities in the void volume. The simple two-step purification procedure provided purification fold and yield of 2.66 and $6.35 \%$, respectively. The low yield value was mainly due to loss of enzyme activity in the ultrafiltration step. Xylanase activity (total activity of 7.16 IU)

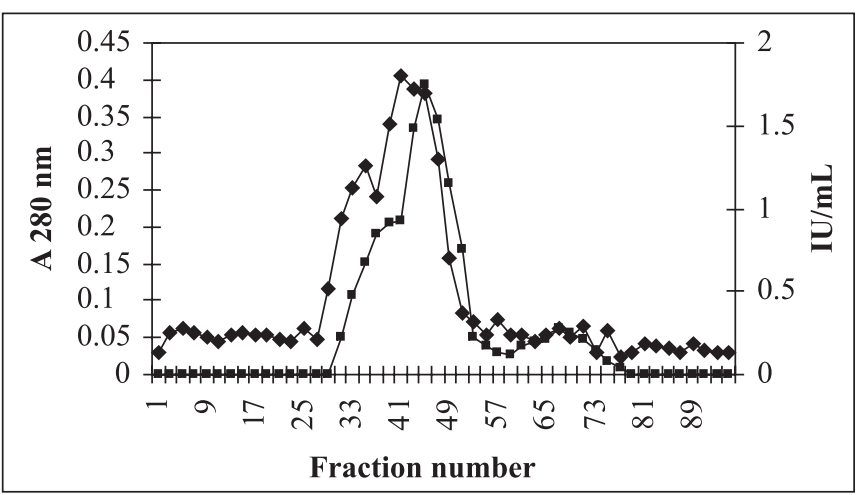

Figure 1. Elution profile of culture supernatant from $C$. thermocellum strain ISO II on Sephacryl S-300. (u) Fractions containing xylanase activity; (n) protein profile at $280 \mathrm{~nm}$.

was found in the ultrafiltrate. According to Filho et al. (5), comparison of these values with those reported for the relevant enzyme systems from other sources is not very meaningful because of the interlaboratory variability in xylanase assays and because xylanases differ from one another with respect to whether their actions require or are hindered by substituents on the substrates used. Furthermore, we can not discard the fact that a high amount of pigment present in culture supernatant, frequently reported after fungi growth on liquid medium containing banana stem as the carbon source (12), interfered in the protein assay. Mohand-Oussaid et al. (13) reported three major fractions containing xylanase activity from Clostridium cellulolyticum after chromatography on a FPLC Superose column, being the first one eluted with the void volume and associated with cellulase activity (avicelase and carboxymethyl cellulase). In comparison with the present enzyme of strain ISO II, $C$. thermocellum strain JW20 also produced an enzyme system with high molecular mass. The ultrafiltration (PM 300) and chromatography in Sephacryl S-300 also showed xylanase, cellulase and mannanase activities eluted with the void volume.

The partially purified enzyme complex of strain ISO II migrated on SDS-PAGE as several bands varying from 25 to 116 kDa (Fig. 2). The zymogram analysis was performed by renaturing the enzyme after electrophoresis and visualized by staining with Congo red. In this case, five bands staining for xylanase activity (X1, X2, X3, X4 and X5) were coincident with those staining for protein. A clear hydrolysis activity zone was formed against a dark background. X1 migrated with molecular mass above $116 \mathrm{kDa}$. The molecular mass values of X2, X3, X4 and X5 were estimated to be $97.4,66,48.5$ and $34 \mathrm{kDa}$, respectively. X3 showed a molecular mass value close to xylanase $\mathrm{XynC}$, one of the major component of $C$. thermocellum F1 cellulosome (8). The identification of the proteins responsible 


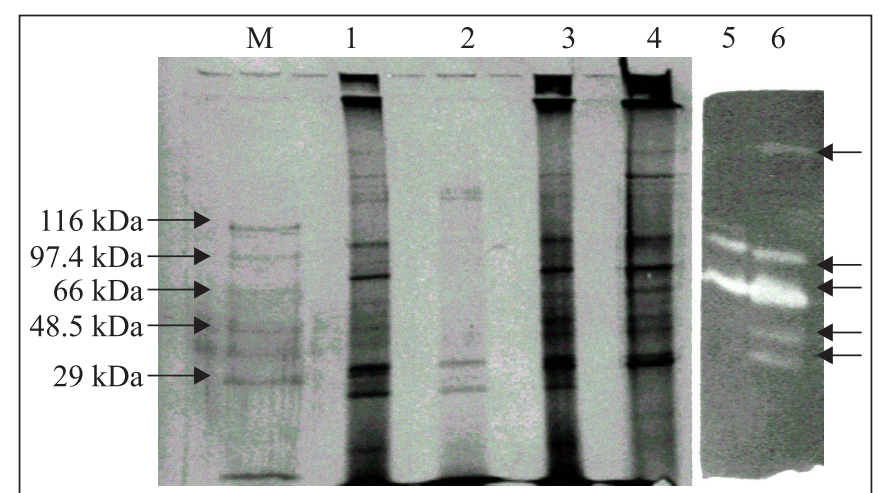

Figure 2. SDS-PAGE and zymogram analysis of enzyme preparations from $C$. thermocellum strain ISO II. Lane M, molecular weight markers; lane 1, culture supernatant; lane 2, ultrafiltrate; lane 3 , concentrated culture supernatant by ultrafiltration; lane 4, Sephacryl S-300 fraction (41-49); lane 5, zymogram analysis of Sephacryl S-300 fraction; lane 6, zymogram analysis of Sephacryl S-300 fraction concentrated 4X.

for cellulase and mannanase activities will help to establish if these activities are displayed by the same or different enzymes. The native PAGE showed a prominent protein band at the top of the gel with a corresponding xylanase activity band (result not shown). It was reported that the cellulosome of $C$. thermocellum YS was composed of a number of different proteins, most of them having enzymatic activity, including cellulase and xylanases $(11,18)$, with four protein bands, being two with molecular mass values above $600 \mathrm{kDa}$ and two around 170 and $240 \mathrm{kDa}$, were detected by the zymogram.

The partially purified enzyme complex exhibited maximal mannanase and xylanase activities at $65^{\circ} \mathrm{C}$ and temperature range of $55-75^{\circ} \mathrm{C}$, respectively. Mannanase activity was stable under alkaline conditions with optimum $\mathrm{pH}$ of 8.0 , while xylanase displayed a higher activity at $\mathrm{pH} 6.0$ and maintained more than $60 \%$ of its activity at $\mathrm{pH}$ range of $3.5-8.5$. It retained $85 \%$ of xylanase activity, after incubation at $65^{\circ} \mathrm{C}$ for $12 \mathrm{~h}$. At the same temperature, mannanase activity showed half-life of $2.5 \mathrm{~h}$. Xylanase from C. acetobutylicum was stable at $60^{\circ} \mathrm{C}$ for $1 \mathrm{~h}$ at $\mathrm{pH} 5.0-6.5$ (14). The optimum temperature and $\mathrm{pH}$ of the isolated cellulosome-type enzyme of Bacteroides sp. strain P-1 were $50^{\circ} \mathrm{C}$ and 6.0 , respectively (15).

The xylan breakdown is dependent on several factors, including enzyme synergism, the interaction with different subsites on the heterogeneous substrate, the interaction of the subunits within the xylan-degrading enzyme system and the probable presence of binding molecules in addition to the catalytic modules (which have different affinities for soluble and insoluble xylan). Despite the difficulties to determine kinetic parameters with a polymeric and rather undefined substrate (in which each molecule has a different number of attacking points), the apparent $\mathrm{Km}$ and Vmax values on soluble and insoluble xylans from oat spelt were measured. The xylanase activity from the partially purified enzyme complex of strain ISO II was most active on insoluble xylan (Table 1). The Km value for soluble xylan was much higher than the insoluble one. The same result was found for the enzyme complex of strain JW20. This might suggest a steric hindrance due to the presence of side-chains groups in soluble xylan (19). On the other hand, the xylanase activity from the partially purified enzyme complex of strain JW20 displayed more affinity against soluble and insoluble xylans with $\mathrm{Km}$ values of 7.6 $\mathrm{mg} / \mathrm{mL}$ and $1.48 \mathrm{mg} / \mathrm{mL}$, respectively. In case of the enzyme complex from strain ISO II, the Km value for galactomannan as the substrate was $0.846 \mathrm{mg} / \mathrm{mL}$.

The influence of various reagents on xylanase and manannase activities from the partially purified enzyme complex of strain ISO II was investigated (Table 2). A significant negative effect on xylanase and mannanase activities was observed with

Table 1. Kinetics parameters on the xylanase activity of the $C$. thermocellum strain ISO II enzyme complex.

\begin{tabular}{lcc}
\hline \multicolumn{1}{c}{ Substrate } & $\begin{array}{c}\mathrm{Km} \\
(\mathrm{mg} / \mathrm{mL})\end{array}$ & $\begin{array}{c}\text { Vmax } \\
(\mathrm{IU} / \mathrm{mL})\end{array}$ \\
\hline Insoluble Oat Spelt Xylan & 1.54 & 1.40 \\
Soluble Oat Spelt Xylan & 11.53 & 11.38 \\
\hline
\end{tabular}

Table 2. Effect of some reagents on the xylanase and mannanase activities of the $C$. thermocellum strain ISO II enzyme complex.

\begin{tabular}{lcc}
\hline & Xylanase & Mannanase \\
\cline { 2 - 3 } Reagent & \multicolumn{2}{c}{ Relative } \\
\hline Control & 100 & 100 \\
NBS & 3.13 & 13.96 \\
DTT & 185.7 & 30.94 \\
DEPC & 100.4 & 45.47 \\
EDC & 113.13 & 50.56 \\
Iodoacetamide & 105 & 45.09 \\
L-Tryptophan & 133.52 & - \\
L-Cysteine & 166.07 & - \\
$\mathrm{Fe}^{3+}$ & 104.2 & 54.15 \\
$\mathrm{Zn}^{2+}$ & 92.4 & 43.96 \\
$\mathrm{Cu}^{2+}$ & 46.6 & 93.20 \\
$\mathrm{Co}^{2+}$ & 2.01 & 36.91 \\
$\mathrm{Al}^{3+}$ & 68.3 & 56.60 \\
$\mathrm{Ca}^{2+}$ & 107 & 36.22 \\
\hline
\end{tabular}


$\mathrm{Co}^{2+}$. Xylanase was highly activated by DTT, L-cysteine and Ltryptophan, suggesting an influence of L-cysteine in the catalysis of xylan. $\mathrm{Ca}^{2+}$ did not affect the xylanase activity. On the contrary to xylanase, DTT, iodoacetamide, $\mathrm{Fe}^{3+}$ and $\mathrm{Ca}^{2+}$ inhibited the mannanase activity. In contrast to above, $\mathrm{Ca}^{2+}$ ions were reported to stimulate the activity of soluble components of cellulosomes (18). Evidence for the involvement of the L-tryptophan residue at the active site is given by the strong inhibition of xylanase and mannanase by NBS (4). The inactivation of mannanase by DEPC and EDC indicates that histidine and carboxyl groups may be involved, respectively in catalysis. In comparison to the above results, xylanase activity from the enzyme of strain JW20 was also activated, to a large extent, by DTT, L-tryptophan and L-cysteine. It was slightly activated by EDC and iodoacetamide.

The partially purified enzyme complex of strain ISO II exhibited no action against PNPG, PNPA and PNPM. It displayed activity towards some polymeric substrate (xylan, filter paper, CMC and galactomannan), but it was not active against pectin. Among them, the highest activity was on xylan from oat spelt (Table 3). The enzyme exhibited a slight activity against PNPX. In opposite to the present enzyme complex, XynC-II of cellulosome from $C$. thermocellum $\mathrm{F} 1$ and cellulosome-type enzymes of Bacteroides succinogenes S-85 showed $\beta$ glucosidase activity $(7,8)$. In addition, the cellulosome of Bacteroides succinogenes S-85 consisted of eight endoglucanases and two xylanases. Most of the cellulosomes are composed of different types of enzymes, including endo- and exo-acting glucanases, xylanase, arabinofuranosidase, mannanase and pectin lyase (1). Twelve cellulosomal enzymes have been identified in C. cellulolyticum, including cellulase, hemicellulase and pectinase (3).

In conclusion, Clostridium thermocellum strain ISO II produced a enzyme complex with xylanase, cellulase and mannanase activities and stability at $65^{\circ} \mathrm{C}$. It showed, at least, 05 subunits with xylanase activity. Further work will be concentrated on the of nature of this enzyme complex (by

Table 3. Substrate specificity of the C. thermocellum ISO II enzyme complex.

\begin{tabular}{cc}
\hline Substrates & Activity $(\%)$ \\
\hline Xylan & 100 \\
CMC & 75 \\
FPA & 22 \\
Pectin & 0 \\
Mannan & 39 \\
PNP-X & 1 \\
PNP-G & 0 \\
PNP-A & 0 \\
PNP-M & 0 \\
\hline
\end{tabular}

western blots using C. thermocellum cohesin or dockerin probes), whether it is organized in cellulosomes or not and the characterization of its cellulase activity. The specific activity on $\mathrm{CMC}$ and filter paper should be quantified and compared to the xylanase and mannanase activities.

\section{ACKNOWLEDGEMENTS}

E.X.F.F. acknowledges the receipt of research fellowship from CNPq. L.R.S.M.,A.M.N. and W.B.V. acknowledge the receipt of maintenance research scholarship from CNPq, PIBIC and CAPES, respectively. The authors thank Dr. Eduardo de Aquino Ximenes for proof reading the manuscript.

\section{RESUMO}

\section{Produção e caracterização de um complexo enzimático de uma nova linhagem de Clostridium thermocellum com enfase em sua atividade de xilanase}

Uma nova linhagem de bactéria (ISO II) foi isolada de esterco bovino e identificada como filogeneticamente próxima à bactéria termofílica Clostridium thermocellum. A nova linhagem produziu atividades de xilanase, mananase, pectinase e celulase quando cultivada em meio de cultura líquido contendo engaço de bananeira como fonte de carbono. O perfil de produção enzimática após crescimento em engaço de bananeira mostrou que as atividades de xilanase e celulase foram detectadas em diferentes períodos de incubação. Um complexo enzimático, contendo atividades de xilanase, celulase e mananase, foi isolado de amostras de sobrenadante do meio de cultura da linhagem ISO II crescida em engaço de bananeira. O complexo foi parcialmente purificado por ultrafiltração e cromatografia de filtração em gel em coluna de Sephacryl S-300. Análise de zimograma mostrou 05 sub-unidades com atividade de xilanase. A amostra enzimática apresentou bandas únicas de proteína e atividade de xilanase após eletroforese sob condições nãodesnaturantes. A hidrólise de xilana foi ótima no intervalo de temperatura de $55-75^{\circ} \mathrm{C}$ e pH 6,0 . A xilanase foi estável a $65^{\circ} \mathrm{C}$, mantendo $80 \%$ de sua atividade original após $12 \mathrm{~h}$ de incubação. Os valores de $\mathrm{Km}$ aparente, usando arabinoxilanas insolúveis e solúveis como substratos, foram 1,54 and $11,53 \mathrm{mg} / \mathrm{mL}$, respectivamente. A xilanase foi ativada por ditiotreitol, Ltriptofano and L-cisteina e fortemente inibida por Nbromosuccinamida e $\mathrm{CoCl}_{2}$. A caracterização da mananase do complexo mostrou $\mathrm{Km}$ e temperatura ótima de $0,846 \mathrm{mg} / \mathrm{mL}$ e $65^{\circ} \mathrm{C}$, respectivamente e $\mathrm{pH} 8,0$. Ao contrário da xilanase, a mananase foi menos estável a $65^{\circ} \mathrm{C}$ com meia vida de $2,5 \mathrm{~h}$ e inibida por ditiotreitol e $\mathrm{Ca}^{2+}$.

Palavras-chave: Clostridium thermocellum; engaço de bananeira; xilanase. 


\section{REFERENCES}

1. Bayer, E.A.; Belaich, J.P.; ShoHam, Y.; Lamed, R. (2006). The cellulosomes: multienzyme machines for degradation of plant cell wall polysachharides. Аnпи. Rev. Microbiol., 58, 521-554.

2. Bradford, M.M. (1976). A rapid sensitive method for the quantitation of microgram quantities of protein utilizing the principle of protein dye binding. Anal. Biochem., 72, 248-254

3. Desvaux, M. (2005). The cellulosome of Clostridium cellulolyticum. Enzyme Microb. Technol., 37, 373-385.

4. Ferreira, H.M.; Filho, E.X.F. (2004). Purification and characterization of a $\beta$-mannanase from Trichoderma harzianum strain T4. Carbohydr. Polym., 57, 23-29.

5. Filho, E.X.F.; Puls, J.; Coughlan, M.P. (1993). Physsicochemical and catalytic properties of a low-molecular-weight endo-1,4- $\beta$-Dxylanase from Myrothecium verrucaria. Enzyme Microb. Technol., $15,535-540$.

6. Filho, E.X.F. (1996). Purification and characterization of $\beta$ glucosidase from solid-state cultures of Humicola grisea var. thermoidea. Can. J. Microbiol., 41, 1-5.

7. Groleau, D.; Forsberg, C.W. (1981). Cellulolytic activity of rumen bacterium Bacteroides succinogenes. Can. J. Microbiol., 27, 517530 .

8. Hayashi, H.; Takagi, K.-I.; Fukumura, M.; Kimura, T.; Karita, S.; Sakka, K.; Ohmiva, K. (1997). Sequence of xynC and properties of $\mathrm{XynC}$, a major component of the Clostridium thermocellum cellulosome. J. Bacteriol., 179, 4246-4253.

9. Hon-Nami, K.; Coughlan, M.P.; Hon-Nami, H.; Carreira, L.H.; Ljungdahl, L.G. (1986). Properties of the cellulolytic enzyme system of Clostridium thermocellum. Biotechnol. Bioeng. Symp., 15, 191205 .

10. Laemmli, U.K. (1970). Cleavage of structural proteins during the assembly of the head of bacteriophage T4. Nature, 227, 680-685.

11. Lamed, R.; Setter, E.; Bayer, E.A. (1983). Characterization of a cellulose-binding, cellulase-containing complex in Clostridium thermocellum. J. Bacteriol., 156, 828-836.

12. Medeiros, R.G.; Soffener, M.L.A.P.; Thomé, J.Á.; Cacais, A.O.G.; Estelles, R.S.; Salles, B.C.; Ferreira, H.M.; Lucena-Neto; A.S.; Silva
Jr., F.G.; FILHO, E.X.F. (2000). The production of hemicellulases by aerobic fungi on medium containing residues of banana plant as substrate. Biotechnol. Prog., 16, 522-524.

13. Mohand-Oussaid, O.; Payot, S.; Guedon, E.; Gelhaye, E.; Youyou, A.; Petitdemange, H. (1999). The extracellular xylan degradative system in Clostridium cellulolyticum cultivated on xylan: evidence for cell-free cellulosome production. J. Bacteriol., 181, 4035-4040.

14. Mursheda, K.A.; Rudolph, F.B.; Bennett, G.N. (2004). Themostable xylanase10B from Clostridium acetobutylicum ATCC824. J. Ind. Microbiol. Biotechnol., 31, 229-234.

15. Ponpium, P.; Ratanakhanokchai, K.; KYU, K.L. (2000). Isolation and properties of a cellulosome-type multienzyme complex of the thermophilic Bacteroides sp. strain P-1. Enzyme Microb. Technol., 26, 459-465.

16. Ratanakhannokchai, K.; Kyu, K.L.; Tanticharoen, M. (1999). Purification and properties of a xylan-binding endoxylanase from alkaliphilic Bacillus sp. strain K-1 Appl. Environ. Microbiol., 65, 694-697.

17. Salles, B.C.; Medeiros, R.G.; Báo, S.N.; Silva Jr., F.G.; Filho, E.X.F. (2005). Effect of cellulase-free xylanases from Acrophialophora nainiana and Humicola grisea var. thermoidea on eucalyptus kraft pulp. Process Biochem., 40, 343-349.

18. Schwarz, W.H. (2001). The cellulosome and cellulose degradation by anaerobic bacteria. Appl. Microbiol. Biotechnol., 56, 634-649.

19. Silva, C.H.C.; Puls, J.; Sousa, M.V.; FILHO, E.X.F. (1999). Purification and characterization of a low molecular weight xylanase from solidstate cultures of Aspergillus fumigatus Fresenius. Braz. J. Microbiol., 30, 114-119.

20. Soffner, M.L.A.P. (2001). Produção de polpa celulósica a partir de engaço de bananeira. São Paulo, Brasil, 67p. (M.Sc. Dissertation. Escola Superior de Agricultura Luiz de Queiroz. USP).

21. Ximenes, F.A.; Silveira, F.Q.P.; Filho, E.X.F. (1996). Production of $\beta$-xylosidase activity by Trichoderma harzianum strains. Curr. Microbiol., 33, 71-77.

22. Zhillina, T.N.; Keybrin, V.V.; Tourova, T.P.; Lysenko, A.M.; Kostrikina, N.A.; Zayarzin, G.A. (2005). Clostridium alkalicellum sp. nov., an obligately alkaliphilic cellulolytic bacterium from a soda lake in the Baikal region. Microbiol., 74, 557-566. 